Marquette University

e-Publications@Marquette

Theology Faculty Research and Publications

Theology, Department of

$1-1-2001$

Overshadowed by Enoch's Greatness: "Two Tablets" Traditions from the Book of Giants to Palaea Historica

Andrei Orlov

Marquette University, andrei.orlov@marquette.edu

Author version. Journal for the Study of Judaism. Vol. 32, No. 1-4 (2001): 137-158. DOI: (C 2001 Brill. Used with permission. 


\title{
Overshadowed by Enoch's Greatness: "Two Tablets" Traditions from the Book of Giants to Palaea Historica
}

\author{
Andrei A. Orlov \\ Theology Department, Marquette University \\ Milwaukee, WI
}

\section{Introduction}

In Jewish Antiquities Josephus unveils a certain tradition according to which the descendants of Seth ...

\begin{abstract}
...discovered the science of the heavenly bodies and their orderly array. Moreover, to prevent their discoveries from being lost to mankind and perishing before they become known-Adam having predicted a destruction of the universe, at one time by a violent fire and at another by a mighty deluge of water-they erected two pillars, one of brick and the other of stone, and inscribed these discoveries on both; so that, if the pillar of brick disappeared in the deluge, that of stone would remain to teach men what was graven thereon and to inform them that they had also erected one of brick. ${ }^{1}$
\end{abstract}

In previous studies, several scholars have noted that although Josephus refers to Seth and his progeny, some features of the "two stelae" story allude to peculiar roles and situations which Jewish lore traditionally associates with the seventh antediluvian patriarch Enoch. One of these features includes the fact that Josephus credited Seth's descendants with the discovery of "the science of the heavenly bodies and their orderly array." Scholars have noted that this role from 
ancient time was traditionally ascribed to Enoch, ${ }^{2}$ who in various Enochic traditions is portrayed as an expert in cosmological, astronomical and calendarical secrets.

Another important detail in Josephus' account is that the "two stelae" passage appears in Jewish Antiquities immediately before the story about the Giants. In 1:73 Josephus tells us that "many angels of God now consorted with women and beget sons who were overbearing and disdainful of every virtue, such confidence had they in their strength; in fact the deeds that tradition ascribes to them resemble the audacious exploits told by the Greeks of the giants." 3 J. VanderKam remarks that the author of Jewish Antiquities does not connect this "Enochic-sounding" tale with the seventh patriarch; "rather, he makes Noah preach to them-unsuccessfully." ${ }^{4}$ He further suggests that "it is not impossible that Josephus took his information from a source such as 1 Enoch 6-11, which mentions Noah but not Enoch. ${ }^{\prime 5}$ It appears that the suggestions of scholars about the connection between the "two stelae" narrative and some Enochic materials are valid and deserve further investigation.

Besides Josephus' writings, ${ }^{6}$ the two tablets/stelae tradition ${ }^{7}$ appears in many other sources, including the Armenian History of the Forefathers and the Armenian Abel, the Latin Life of Adam and Eve, various Christian Chronographers, a fragment from Greek Palaea Historica, and some other materials. ${ }^{8}$ Even a brief review of these documents shows that the "two stelae" narrative contains traces of the Enochic traditions. The purpose of this chapter is to investigate these associations between the "two stelae" tradition and Enochic tradition.

\section{I. "Shadows" of the Enochic Roles}

Josephus' account of the two stelae specifically credited the architects of the antediluvian pillars (in Josephus' case, the Sethites ${ }^{9}$ ) with the discovery of the science of astronomy. It was noted earlier that this reference alludes to the seventh antediluvian patriarch, who, according to the Astronomical Book, first received such knowledge from the archangel Uriel during his celestial tour. A closer look at Josephus' passage and other textual evidence associated with the "two stelae" traditions shows that the discovery of astronomy is not the only Enochic achievement that appears to be borrowed in the variety of these stories. It seems that the employment of different Enochic roles is not a rare feature of these traditions. This section of our research will seek therefore to uncover the hidden "shadows" of the Enochic roles that were implicitly preserved in the various "two stelae" narratives. 
NOT THE PUBLISHED VERSION; this is the author's final, peer-reviewed manuscript. The published version may be accessed by following the link in the citation at the bottom of the page.

\section{Foreknowledge of the Destruction of the World}

An account of the Byzantine chronographer John Malalas is one of the many witnesses to the two stelae traditions in medieval Christian chronicles. In the two tablets' story, in his Chronography 1:5, he seems to depend entirely on Josephus' evidence. ${ }^{10}$ However, his retelling helps us to see some new angles in the familiar story. In his narration of Josephus' account, Malalas points to the foreknowledge of the future destruction of the world as an important characteristic of the authors of the antediluvian stelae. ${ }^{11} \mathrm{He}$ stresses that "Seth's descendants were god-fearing men and, having foreknowledge of the destruction, or change, that was then to affect mankind, made two tablets, the one of stone and the other of clay. ${ }^{\prime 12}$ Again, this motif of the foreknowledge of the future destruction of the earth returns us to some situations and roles associated with Enoch.

In the Enochic traditions only a few prediluvian persons received revelation about the upcoming destruction of the world. Among them Enoch and Noah can be found. Although Noah is informed about the future destruction of the world, the specific function of writing down this revelation is usually assigned to Enoch, who in the Book of Watchers, ${ }^{13}$ Jubilees, ${ }^{14}$ and in the Book of Giants, ${ }^{15}$ is often portrayed as the one who writes and delivers the warnings about the future destruction to the Watchers/Giants and to humans. An important detail in these Enochic traditions relevant to the "two stelae" story (which entertains the idea about dual destruction of the world by water and fire), is the fact that, in contrast to Noah who is informed about the Flood, Enoch, due to the specifics of his mediating affairs, also knows about the upcoming destruction of the Watchers/Giants by fire.

\section{Art of Writing}

Josephus' passage pictures the descendants of Seth as the ones who inscribe astronomical discoveries on the pillars. It seems that the various "two stelae" stories seek to emphasize the scribal expertise of the Sethites by attributing to them even the invention of writing. Although Josephus' fragment does not say directly that the descendants of Seth invented writing, other "two stelae" accounts often do so. Thus, the Armenian Abel depicts Enosh as the one who invented the letters. ${ }^{16}$ The anonymous chronicler included in the CSHB edition of John Malalas ${ }^{17}$ and the Latin Life of Adam and Eve also point to the Sethites' invention of the art of writing by referring to Seth as to the one "who devised the caps of letters."18

Journal for the Study of Judaism, Vol. 32 (2001): pg. 137-158. DOI. This article is (C) Brill Academic Publishers and permission has been granted for this version to appear in e-Publications@Marquette. Brill Academic Publishers does not grant permission for this article to be further copied/distributed or hosted elsewhere without the express permission from Brill Academic Publishers. 
Upon observing these references to the scribal activities of the various authors of the antediluvian stelae, one can easily recognize certain similarities to Enoch's figure. As was noted earlier, he, similar to the Sethites, was also involved in producing the antediluvian writings dedicated to the astronomical secrets.

The excursus about the unique scribal functions of the seventh antediluvian patriarch in the Enochic traditions can begin with the passage found in 2 Enoch 22. It provides a striking picture of Enoch's initiation into the scribal activities which takes place near the Throne of Glory. During this initiation the Lord himself commands the archangel Vereveil to give a pen to Enoch so that he can write the mysteries explained to him by the angels. This tradition about the scribal functions of the patriarch is already documented in the earliest Enochic literature. ${ }^{19}$ The Book of Giants fragments label Enoch as the distinguished scribe. ${ }^{20}$ In Jub. 4:17, he is attested as the one who "learned (the art of) writing, instruction, and wisdom and who wrote down in a book the signs of the sky..."21 In the Merkabah tradition, Enoch/Metatron is also depicted as a scribe who has a seat (later, a throne) in the heavenly realm. ${ }^{22}$ The theme of Enoch/Metatron's scribal functions became a prominent motif in the later Rabbinic tradition, where according to $b$. Hag. 15a, the privilege of "sitting" beside God was accorded solely to Metatron by virtue of his character as a "scribe"; for he was granted permission as a scribe to sit and write down the merits of Israel.

\section{Dissemination and Preservation of the Celestial Knowledge}

Josephus' passage makes clear that the purpose of building the stelae was to preserve the astronomical knowledge for the postdiluvian generations. He writes that the Sethites wanted to build the pillars in order "to prevent their discoveries from being lost to mankind and perishing before they became known." 23 A similar motif can be found in Enochic traditions where Enoch's writings often serve for the same purpose of the preservation of knowledge in light of the impending flood. In 2 Enoch 33 the Lord tells Enoch that the main function of his writings is the dissemination of knowledge and its preservation from the impending catastrophe:

And give them the books in your handwriting, and they will read them and they will acknowledge me as the Creator of everything.... And let them distribute the books in your handwritings, children to children and family to family and kinfolk to kinfolk... So I have commanded my angels, Ariukh and Pariukh, whom I have appointed to the earth as their guardians, and I

Journal for the Study of Judaism, Vol. 32 (2001): pg. 137-158. DOI. This article is @ Brill Academic Publishers and permission has been granted for this version to appear in e-Publications@Marquette. Brill Academic Publishers does not grant permission for this article to be further copied/distributed or hosted elsewhere without the express permission from Brill Academic Publishers. 
NOT THE PUBLISHED VERSION; this is the author's final, peer-reviewed manuscript. The published version may be accessed by following the link in the citation at the bottom of the page.

commanded the seasons, so they might preserve them [books] so they might not perish in the future flood which I shall create in your generation. ${ }^{24}$

Despite the apparent "esoteric" character of the knowledge conveyed by the angels and the Lord to the seventh antediluvian patriarch, the dissemination of this information remains one of the major functions of Enoch-Metatron in various Enochic traditions. They depict him as the one who shares astronomical, meteorological, calendarical, and eschatological knowledge with his sons and others during his short visit to the earth. He also delivers knowledge about future destruction to the Watchers/Giants. In the Merkabah tradition, Enoch-Metatron is also responsible for transmitting the highest secrets to the Princes under him, as well as to humankind. $\mathrm{H}$. Kvanvig observes that "in Jewish tradition Enoch is primarily portrayed as a primeval sage, ${ }^{25}$ the ultimate revealer of divine secrets." 26

\section{Expertise in Astronomical and Calendar Science}

Josephus credited the authors of the antediluvian stelae with the discovery of astronomical and apparently calendarical knowledge, since his passage contains the reference to the science of the heavenly bodies and "their orderly array." 27 Another "two stelae" text, drawn from Michael Glycas, also refers to the Sethites discovery of the calendar. It reads that "the divine Uriel, descended to Seth and then to Enoch and taught them the distinction between hours, months, seasons and years...." 28 The "two stelae" traditions also claimed that the Sethites gave astronomical bodies their names. For example, the Armenian account of two stelae found in Abel explicitly supports this tradition by referring to Enosh, son of Seth, as the one who "called the planets by name." 29 This tradition, with a reference to Josephus, is repeated in the Chronicle of John Malalas. ${ }^{30}$ The account about the naming of the planets also appears in the anonymous chronicler included in the CSHB edition of John Malalas. ${ }^{31}$ In this text Seth is the one who called the planets by name. The account even refers to the specific Greek names, which Seth gave to the planets.

The depictions of the Sethites' achievements in astronomical science echoes traditional Enochic roles. Already in the early Enochic booklets of 1 Enoch, Enoch is portrayed as the one who learned knowledge about the movements of the celestial bodies from the archangel Uriel. In the Astronomical Book the knowledge and revelation of cosmological and astronomical secrets become major functions of the elevated Enoch. The origin of these roles in Enochic traditions can be traced to 1 Enoch 72:1,74:2, and 80:1. In 1 Enoch $41: 1$ Enoch is depicted as the one who "saw all secrets of heaven..." 32 
Jub. 4:17 also attests to this peculiar role of the seventh patriarch. A large portion of 2 Enoch is dedicated to Enoch's initiation into the treasures of meteorological, calendarical and astronomical lore during his celestial tour. Later Merkabah developments also emphasize the role of Enoch as the "Knower of Secrets." According to 3 Enoch 11:2, Enoch-Metatron is able to behold "deep secrets and wonderful mysteries." 33

Several scholars have noted the possible Enochic prototype behind the Sethites' role as the experts in astronomical and calendarical science. M. Stone, remarking on the passage from Abel, observes that "the tradition connecting Seth with the invention of the names of the stars is unusual. It may be related to the more prevalent tradition attributing the invention of both writings and astronomy to Enoch." 34

In the distant past, R. H. Charles also noted that in the Byzantine chronicles many discoveries attributed to Seth reflect a transfer of "Enoch's greatness to Seth." ${ }^{35}$ In reference to Charles' comments, W. Adler observes that the tradition attested in the "two stelae" narrative of Josephus and widespread in the Byzantine chronicles "became the basis for the attribution to Seth of numerous revelations and discoveries, many of them precisely parallel to those imputed to Enoch." 36

\section{Preaching to the Giants}

It was observed earlier that in Josephus" account the "two stelae" story is attached to the Watchers/Giants narrative. The author of Jewish Antiquities portrays Noah's unsuccessful preaching to the Giants. J. Vanderkam notes that "it is not impossible that Josephus took his information from a source such as 1 Enoch 6-11, which mentions Noah but not Enoch, although in those chapters Noah does not try to improve the overbearing giants. ${ }^{137}$ Indeed, despite the fact that some traditions point to a possible close relationship between Noah and the Giants in view of his miraculous birth, 38 his "experience" in dealing with the Giants in Enochic traditions cannot be even compared with Enoch's record. In various Enochic materials, Enoch is pictured as the special envoy of the Lord to the Watchers/Giants with a special, long-lasting mission to this rebellious group, both on earth and in other realms. The Book of the Watchers depicts him as the intercessor to the fallen angels. According to Jub. 4:22, Enoch "...testified to the Watchers who had sinned with the daughters of men... Enoch testified against all of them."39 In the Book of Giants Enoch delivers the written "sermon," reprimanding the 
NOT THE PUBLISHED VERSION; this is the author's final, peer-reviewed manuscript. The published version may be accessed by following the link in the citation at the bottom of the page.

Watchers/Giants' sinful behavior and warning them about the upcoming punishment. ${ }^{40} 2$ Enoch 18 portrays Enoch's "preaching" to the Watchers during his celestial tour, encouraging them to start the liturgy before the face of the Lord. ${ }^{41}$

An examination of the surviving evidences to the "two stelae" story shows that some of them attest to a tradition different from that attested in Josephus. Instead of Noah's preaching to the Giants, they portray Enosh's preaching to the sons of God. Two references about the preaching to the sons of God in the "two stelae" traditions are especially important. Both of them have been preserved in the Armenian language and include the Armenian History of the Forefathers and Abel.

The Armenian History of the Forefathers 40-44 deals with the two stelae story. In 45 the narrative continues with the description of Enosh's preaching:

40 Sixth, because he [Enosh] set up two pillars against the sons of Cain, these are hope and good works, which they did not have.

41 Seventh, that he made writings and wrote on stela(e) of baked brick and bronze, and he prophesied that the earth will pass through water and fire on account of the sins of humans. And he cast the baked brick into the water and the bronze into the fire, in order to test (them), if the fire was to come first, the bronze would melt, and if the water was to come first, the brick would be destroyed. And by this means he learned that the water was destined to come, and then fire. And these are a work of hope.

42 And the writings on the two stelae told the names of all things, for he knew that by lispers, stutterers and stammerers the language was destined to be corrupted.

43 And they confused and changed the names of the objects that had come into being, which Adam had named and fixed. On this account he wrote (them) on the two stelae and left them, so that if the water came first and destroyed the pillar of baked brick, the bronze writing and names of things would remain, so that after the flood and the passing of times it might come to use.

44 Likewise, also if the fiery flood ${ }^{42}$ and the bronze (i.e., stele) melted and ruined the writing, the earthen one might remain more baked. And this is a true action of hope.

45 Eighth, that Enosh preached to his sons to take on a celibate and immaculate way of life, for the sake of the just recompense of God. Two hundred persons, having learned this from him, remembered the life of paradise and established a covenant for themselves to live purely. And they were called "sons of God" on account of hope and of being busy with heavenly desire. For the glory of Christ, our hope. ${ }^{43}$

Journal for the Study of Judaism, Vol. 32 (2001): pg. 137-158. DOI. This article is (C) Brill Academic Publishers and permission has been granted for this version to appear in e-Publications@Marquette. Brill Academic Publishers does not grant permission for this article to be further copied/distributed or hosted elsewhere without the express permission from Brill Academic Publishers. 
NOT THE PUBLISHED VERSION; this is the author's final, peer-reviewed manuscript. The published version may be accessed by following the link in the citation at the bottom of the page.

The Armenian Abel also portrays Enosh as the author of the stelae. However, in contrast to the previous text, it connects the tradition about the sons of God with Enoch and his antediluvian writings that survived the Flood:

4.3 However, we found that Enosh, son of Seth, made the letter(s) and called the planets by name.

4.4 And he prophesied that this world would pass away twice, by water and by fire. And he made two stelae, of bronze and of clay, and he wrote upon them the names of the parts of creation which Adam had called. He said, "If it passes away by water, then the bronze (will) remain, and if by fire, then the fired clay."

4.5 And they were called true sons of God because God loved them, before they fornicated.

4.6 By this writing the vision of Enoch was preserved, he who was transferred to immortality. And after the Flood, Arpachshad made Chaldean writing from it, and from the others (were made). ${ }^{44}$

Several details in these two Armenian accounts about the preaching to the sons of God are important for establishing possible connections with Enochic traditions:

1. Both texts use the terminology of "sons of God";

2. History of the Forefathers applies this term to the audience of Enosh's preaching;

3. History of the Forefathers also specifies the number of the sons of God as two hundred persons;

4. Abel 4.5 describes the sons of God as those whom God loved before they fornicated;

5. History of the Forefathers 45 refers to the possible angelic status of the sons of God, describing them as those who "remembered the life of paradise" and "being busy with the heavenly desire." 45

An important characteristic in both texts is the reference to the "sons of God." Who are these sons of God? In the Bible the term can be traced to the Giants story in Gen 6. Scholars, however, note that in later Christian accounts the term "the sons of God" was often used in reference to the Sethites. ${ }^{46}$ They also note the peculiar tendency to equate the Watchers and the Sethites in various accounts of the "two stelae" tradition. ${ }^{47}$ It is quite possible that the authors of the two Armenian accounts understand the sons of God to be the Sethites. It is also evident that the prototype of the story was connected with the Watchers' story and Enoch's preaching to them. Several details in the texts point to this connection. First, History of the Forefathers 45

Journal for the Study of Judaism, Vol. 32 (2001): pg. 137-158. DOI. This article is @ Brill Academic Publishers and permission has been granted for this version to appear in e-Publications@Marquette. Brill Academic Publishers does not grant permission for this article to be further copied/distributed or hosted elsewhere without the express permission from Brill Academic Publishers. 
NOT THE PUBLISHED VERSION; this is the author's final, peer-reviewed manuscript. The published version may be accessed by following the link in the citation at the bottom of the page.

defines the number of "the sons of God" as two hundred. In the Enochic traditions this numeral appears often in reference to the number of the Watchers who descended on Mount Hermon.48 Another important feature in the Armenian accounts is the description of the sons of God as those whom God loves before they fornicated. It may allude to the exalted status of the Watchers and their leaders before their descent on Mount Hermon.

The important aspect of the preaching story found in History of the Forefathers 45 involves the question why instead of Noah or Enoch this text depicts Enosh as the one who preaches to the sons of God. It is possible that Enoch's name here was misplaced with that of Enosh. M. Stone observes that Enosh and Enoch are often confused in the Armenian tradition. ${ }^{49}$ It is noteworthy that the story about the sons of God found in $A b e l$ uses Enoch instead of Enosh. It might refer to the Enochic background of the Armenian accounts. The "two stelae" tradition from the Latin Life of Adam and Eve further supports our contention. Chapter 53 of the Life also has the passage about Enoch's "preaching" immediately after the "two stelae" account. ${ }^{50}$

\section{Enochic Authorship of the Tablets}

\section{Palaea's Account}

In Palaea Historica, ${ }^{51}$ the Byzantine medieval compendium, the following passage, referring to Enoch's authorship of the two tablets can be found:

Concerning Enoch. Enoch was born and became a good and devout man, who fulfilled God's will and was not influenced by the counsels of the giants. For there were giants (on earth) at that time. And Enoch was translated (to heaven) by God's command, and no one saw [how] his removal [happened].

Concerning Noah. In the days when the giants were around and did not want to glorify God, a man was born whose name was Noah, who was devout and feared God, and like Enoch he was not influenced by the giants' counsels....

...When the giants heard that the righteous Noah was building an ark for the Flood, they laughed at him. But Enoch, who was still around, was also telling the giants that the earth would either be destroyed by fire or by water. And the righteous Enoch was doing nothing else but sitting and writing on marble (tablets) and on bricks the mighty works of God which had happened from the beginning. For he used to say: "If the earth is destroyed by fire, the bricks will be preserved to be a reminder [for those who come after] of the mighty works of God which have happened from the beginning; and if the earth is destroyed by water, the marble tablets will be preserved." And Enoch used to warn the giants about many things, but they remained stubborn and impenitent, nor did they want to glorify the Creator, but instead each [of them] walked in his own will of the flesh....52

Journal for the Study of Judaism, Vol. 32 (2001): pg. 137-158. DOI. This article is (C) Brill Academic Publishers and permission has been granted for this version to appear in e-Publications@Marquette. Brill Academic Publishers does not grant permission for this article to be further copied/distributed or hosted elsewhere without the express permission from Brill Academic Publishers. 
NOT THE PUBLISHED VERSION; this is the author's final, peer-reviewed manuscript. The published version may be accessed by following the link in the citation at the bottom of the page.

A glance at the Palaea fragment shows that it is completely different from the previous "two stelae" accounts based on Josephus' story. The main distinction is that Enoch, who in the Sethites' accounts occupied a peripheral role, stays now in the center of his own authentic narrative. The fact that the preaching to the Giants preceded the writing of the stelae emphasizes that the focus of the story was changed and the proper order of the events was restored.

This leads to important corrections. Unlike the Sethites in Josephus' account, Enoch does not try to preserve only one facet of the antediluvian knowledge, astronomical or calendar, but attempts to save the totality of the celestial knowledge, as it was commanded to him by the Lord in some Enochic accounts. Just as in 2 Enoch, he writes about everything that happened before him.

In contrast to the Sethites' account, the Palaea does not mention the name of Adam. In the Sethites' "two stelae" stories, Adam serves as the mediator of the divine revelation, through whom the Sethites receive the knowledge about the future destruction of the earth. The Palaea does not refer to the Adamic tradition, since Enoch and Noah, unlike the Sethites, have direct revelation from God about the upcoming destruction.

These differences indicate that the author of the passage in Palaea Historica seems to draw on traditions different from those represented in Josephus. It is also evident that the stories in Palaea and Josephus ${ }^{53}$ rely on the common source in which Noah's figure was exalted. ${ }^{54}$ In the Josephus account, however, the Noachic tradition ${ }^{55}$ appears to be overwritten by the Adamic tradition. ${ }^{56}$ In the Pseudepigrapha and the Qumran writings, the Adamic and PriestlyNoah tradition often compete with and suppress each other. The "two stelae" story from Jewish Antiquities might contain the traces of such polemics.

\section{Water and Fire}

Among the several two stelae/tablets stories we have examined, the passage from Palaea Historica baffles the reader more than the rest. It portrays Enoch unceasingly writing on the tablets made from marble and brick. The depiction takes place in the midst of the Noachic narrative where the theme of the Flood comes to the fore. The reference to the tablets for the fire destruction therefore appears puzzling since the assurance of the approaching Flood makes them completely unnecessary. Why does Enoch need the tablets made from

Journal for the Study of Judaism, Vol. 32 (2001): pg. 137-158. DOI. This article is (C) Brill Academic Publishers and permission has been granted for this version to appear in e-Publications@Marquette. Brill Academic Publishers does not grant permission for this article to be further copied/distributed or hosted elsewhere without the express permission from Brill Academic Publishers. 
the two types of material if it is already certain that the earth will perish inevitably in the imminent Flood?

The answer to these questions can possibly be found by reference to the Book of Giants, where the theme of the Enochic tablets also looms large. Although the temporal locus of this narrative appears to be placed before the approaching Flood, it seems to entertain the idea of the dual destruction of the world, by water and by fire.

One of the Qumran Aramaic fragments of the Book of Giants (4Q530) depicts a dream in which a giant sees the destruction of a certain "garden" by water and fire. ${ }^{58}$ Most scholars take this symbolic dream to signify the upcoming destruction of the world by water and fire. J. Reeves observes that "the Qumran passage reflects an eschatological conception ${ }^{59}$ well attested in the Hellenistic era of a dual cosmic destruction, one of which employs water (mabbul shel mayim) and the other fire (mabbul shel 'esh)."60

In their analysis of the dream about the destruction of the garden, scholars have tried to establish a connection between the material from 4Q530 and the late Rabbinic text known as the Midrash of Shemhazai and Azael. ${ }^{61}$ This rabbinic account was allegedly a part of the no longer extant Midrash Abkir. ${ }^{62}$ Some scholars point to striking similarities between Midrash of Shemhazai and Azael and the dream from $4 Q 530 .{ }^{63}$ Similarly to $4 Q 530$, the midrash also portrays the giant's dream about the destruction of the garden in a way that symbolizes the destruction of the world. ${ }^{64}$

The Midrash of Shemhazai and Azael has survived in several manuscripts, ${ }^{65}$ including the composition known as the Chronicles of Jerahmeel. It is noteworthy that in the Chronicles of Jerahmeel, the Midrash of Shemhazai and Azael is situated between two almost identical stories connected with the "two stelae" tradition. In M. Gaster's edition ${ }^{66}$ of the Chronicles, the Midrash Shemhazai and Azael occupies chapter 25 . In chapter 24 , the following story can be found:

... Jubal discovered the science of music, whence arose all the tunes for the above two instruments. This art is very great. And it came to pass, when he heard of the judgments which Adam prophesied concerning the two trials to come upon his descendants by the flood, the destruction and fire, he wrote down the science of music upon two pillars, one of white marble, and the other of brick, so that if one would melt and crumble away on account of the water, the other would be saved. 24:6-9.67

Journal for the Study of Judaism, Vol. 32 (2001): pg. 137-158. DOI. This article is (C) Brill Academic Publishers and permission has been granted for this version to appear in e-Publications@Marquette. Brill Academic Publishers does not grant permission for this article to be further copied/distributed or hosted elsewhere without the express permission from Brill Academic Publishers. 
In chapter 26 of Gaster's edition, right after the Midrash of Shemhazai and Azael, the story about the two pillars is repeated again68 in a slightly different form. ${ }^{69}$ The second time, it is placed before the account about Enoch and the Flood. ${ }^{70}$

An important detail in Jubal's fragments is that they do not connect the "two stelae" narrative with the Sethites, the constant feature of the stories based on the Josephus account. ${ }^{71}$ Jubal represents the Cainites. Both texts from the Chronicles of Jerahmeel do not seem to object to this line of descent. Jubal, as well as the Sethites, knows about Adam's prophecy. The reference to Adam in Jubal's story might indicate that the main theological concern of the writers/editors of the "two stelae" accounts was not the prominent role of the Sethites, but rather Adam's prophecy about the upcoming destruction of the earth. Here again the traces of the Adamic tradition(s) are clearly observable.

It was mentioned earlier that the Book of Giants entertains the idea of the dual destruction of the world, by water and fire. Although the Bible and the Pseudepigrapha commonly refer to the Flood they rarely use the image of the earth's destruction by fire. It also appears that the Enochic Watchers/Giants account is one of the few places in intertestamental Jewish literature where the necessity of such fire annihilation finds a consistent theological explanation. In spite of the fragmentary nature of the extant materials, they nevertheless are able to demonstrate the complexity of the theme in the Book of Giants.

It should be noted that the allusions to the future judgment by fire are not confined only to the Aramaic portions found at Qumran. The fragments of the Book of Giants which have survived in other languages give additional details of this theme in the book. ${ }^{72}$ They include several Manichaean fragments in Middle-Persian, Partian, and Coptic which address the motif the annihilation of the world by fire. ${ }^{73}$

\section{Tablets}

We mentioned earlier that there are some indications that the theme of the Enochic tablets play quite a prominent role in the Book of Giants. Unfortunately, the fragmentary character of the extant materials does not allow us to draw a coherent picture of the "tablets" tradition in this enigmatic text. It is important, however, to emphasize several features of this theme relevant to the subject of our investigation:

Journal for the Study of Judaism, Vol. 32 (2001): pg. 137-158. DOI. This article is (C) Brill Academic Publishers and permission has been granted for this version to appear in e-Publications@Marquette. Brill Academic Publishers does not grant permission for this article to be further copied/distributed or hosted elsewhere without the express permission from Brill Academic Publishers. 
1. It is clear that the story of the tablets represents a major theme in the original Book of Giants. In a relatively small amount of the extant Qumran materials of the Book of Giants, the contextual reference to the tablet(s) occurs six times in three fragments: $2 Q 26 ;{ }^{74} 4 Q 203$ 7BII, ${ }^{75}$ and $4 Q 2038 .{ }^{76}$ The tablets are also mentioned in the Sundermann fragment of the Manichaean Book of Giants ${ }^{77}$ and in the Midrash of Shemhazai and Azael. ${ }^{78}$

2. Several fragments of the Book of Giants refer to two tablets. The two tablets are addressed in $4 Q 2037 \mathrm{BII}$ and $4 Q 2038$. This number of tablets also occurs in the Middle Persian fragment of the Book of Giants published by W. Sundermann. ${ }^{79}$

3. The extant materials ascribe the authorship of the tablets to Enoch. $4 Q 2038$ refers to a "copy of the seco[n]d tablet of [the] le[tter...] by the hand of Enoch, the distinguished scribe..." ${ }^{\prime 80}$ Enoch is described as the distinguished scribe. He is also portrayed as the one who copied the tablets, since the reference to a "copy of the seco[n]d tablet" in 4Q203 8:3-4 occurs in conjunction with his name.

4. The reference to Enoch's copying of the tablet is quite intriguing, since "copying" plays a decisive role in the various two tablets/stelae materials mentioned in our research earlier, which are construed around the idea of the duplication of the tablets in various materials.

5. In conclusion to this section, it should be noted that the Book of Giants' materials seem to contain traces of a more developed and multifaceted tradition about the tablets than the later "two tablets" accounts. In the Book of Giants copying is only one of the several roles Enoch has in relation to the tablets. In this text the theme of tablets seems closely connected with other traditional roles of the elevated Enoch such as those of Mediator ${ }^{81}$ and the Witness of the Divine Judgment. ${ }^{82}$ These Enochic roles are reflected in the peculiar functions of the tablets in the Book of Giants. The tablets serve as a record of accusations against the Watchers/Giants, representing the written account of their sins. ${ }^{83}$ The tablets are also a mediating tool in the dialogue between God and the Watchers/Giants via the representatives of the both parties-Enoch and Mahaway. ${ }^{84}$ These peculiar functions are only slightly hinted at in later tablet traditions. ${ }^{85}$ The later "two tablets" traditions seem primarily preoccupied with the idea of copying, where the tablets are portrayed as the specific means for the preservation of knowledge in the impending catastrophe. They therefore appear to represent only one facet of the complicated story of the Enochic tablets.

Conclusion

Journal for the Study of Judaism, Vol. 32 (2001): pg. 137-158. DOI. This article is (C) Brill Academic Publishers and permission has been granted for this version to appear in e-Publications@Marquette. Brill Academic Publishers does not grant permission for this article to be further copied/distributed or hosted elsewhere without the express permission from Brill Academic Publishers. 
NOT THE PUBLISHED VERSION; this is the author's final, peer-reviewed manuscript. The published version may be accessed by following the link in the citation at the bottom of the page.

1. The first part of our research deals with the "two stelae" stories based on the Josephus account. Our analysis of these accounts shows that they contain traces of the Enochic traditions. It appears that these "two stelae" stories interact with the Enochic traditions by way of attributing various Enochic roles to the alleged "authors" of the antediluvian stelae. These "authors" are usually portrayed as the Sethites. The attribution involves substantial rewriting of the original Enochic motifs and themes. The analysis also shows that the interaction of "two stelae" stories with Enochic traditions seems to involve some details of the Watchers/Giants' story.

2. The passage found in Jewish Antiquities and the stories which are based on this account demonstrate the influence of the Adamic tradition(s). In these accounts Adam's prophecy about the upcoming destruction of the earth serves as the reason for the making of the antediluvian stelae.

3. It is also possible that despite the decisive formative influence Josephus' account had on the subsequent "two stelae" stories, it itself represents the Adamic revision of the original two stelae/tablets account based on Noachic/Enochic traditions. Noah's preaching to the Giants in Josephus' account, the host of Enochic roles, and remnants of the Watchers/Giants story in various "two stelae" narratives may point to the Noachic/Enochic prototype.

4. It is possible that the Noachic/Enochic prototext was dedicated neither to the Sethites nor the Cananites who followed Adam's instructions, but rather to Enoch and Noah.

5. The tradition preserved in Palaea Historica might directly derive from this Noachic/Enochic original, which has not undergone Adamic revisions.

6. It is possible that some "two stelae" accounts might be connected with, or maybe even derived from, traditions similar to the Book of Giants. The circulating of materials related to the Book of Giants traditions in medieval Christian milieux does not seem impossible. W. Adler observes that some passages found in Syncellus "imply the existence of some work circulating in the name of the Giants." 86 He also demonstrates that such references sometimes occur in connection with the two stelae/tablets traditions. ${ }^{87}$

7. In an attempt to find possible antecedents for the two tablets story in the known Noachic/Enochic materials the tablet tradition(s) preserved in the Book of Giants fragments were explored.

8. While our comparative analysis of the "two stelae" traditions with materials from the Book of Giants revealed some suggestive similarities, it is evident that the extremely fragmentary character of the extant materials from the Book of Giants cannot give us definite evidence about the presence of the two stelae/tablets tradition in the original document.

Journal for the Study of Judaism, Vol. 32 (2001): pg. 137-158. DOI. This article is @ Brill Academic Publishers and permission has been granted for this version to appear in e-Publications@Marquette. Brill Academic Publishers does not grant permission for this article to be further copied/distributed or hosted elsewhere without the express permission from Brill Academic Publishers. 
NOT THE PUBLISHED VERSION; this is the author's final, peer-reviewed manuscript. The published version may be accessed by following the link in the citation at the bottom of the page.

Notes

1 Josephus, Jewish Antiquities (LCL; tr. H. S. J. Thackeray; Cambridge: Harvard University Press/London: Heinemann, 1967), 4.33.

2 J. VanderKam observes that in the passage about the discovery of astronomical learnings, Josephus "attributes the achievement not to Enoch but, instead, to the descendants of Seth." J. VanderKam, Enoch: A Man for All Generations (Columbia: University of South Carolina, 1995), 153. H. S. J. Thackeray also notes the "Enochic role" in Josephus' passage. See: Josephus, Jewish Antiquities (LCL; tr. H. S. J. Thackeray; Cambridge: Harvard University Press/London: Heinemann, 1967), 4.32. 3 Josephus, Jewish Antiquities (LCL; tr. H. S. J. Thackeray; Cambridge: Harvard University Press/London: Heinemann, 1967), 4.35.

4 J. VanderKam, Enoch: A Man for All Generations, 153.

5 J. VanderKam, Enoch: A Man for All Generations, 153.

${ }^{6}$ Another important early source about the antediluvian stelae is Jub. 8:1-3. On the tablets' tradition in the Book of Jubilees see: F. García Martínez, "The Heavenly Tablets in the Book of Jubilees," Studies in the Book of Jubilees (eds. M. Albani et al.; TSAJ, 65; Tübingen: Mohr/Siebeck, 1997), 243-60. On the antediluvian writings see also: R. Eppel, "Les tables de la loi et les tables célestes," RHPhR 17 (1937) 401-12; P. Grelot, "La légende d'Hénoch dans les apocryphes et dans la Bible: origine et signification," RSR 46 (1958) 9-13; M. Hengel, Judaism and Hellenism (2 vols.; Philadelphia: Fortress, 1974), 1.24243; H. L. Jansen, Die Henochgestalt: Eine vergleichende religionsgeschichtliche Untersuchung (Norske Videnskaps-Akademi i Oslo II. Hist.-Filos. Klasse, 1; Oslo: Dybwad, 1939), 28ff; S. M. Paul, "Heavenly Tablets and the Book of Life," JANES 5 (1973) 345-52; W. Speyer, Bücherfunde in der Glaubenswerbung der Antike (Göttingen: Vandenhoeck \& Ruprecht, 1970), 110-24.

7 On the "two stelae" traditions see: W. Adler, Time Immemorial: Archaic History and Its Sources in Christian Chronography from Julius Africanus to George Syncellus (Dumbarton Oaks Studies, 26; Washington: Dumbarton Oaks Research Library and Collection, 1989); D. Flusser, "Palaea Historica-An Unknown Source of Biblical Legends," Studies in Aggadah and Folk-Literature (eds. J. Heinemann and D. Noy; Scripta Hierosolymitana, 22; Jerusalem: Magnes, 1971), 51-2; S. D. Fraade, Enosh and His Generation (SBLMS, 30; Atlanta: Scholars, 1984), 19, 25-6; L. Ginzberg, Legends of the Jews (7 vols.;

Philadelphia: The Jewish Publication Society of America, 1955), 1.12022, 5.148-50; A. F. J. Klijn, Seth in Jewish, Christian and Gnostic Literature (SNT, 46; Leiden: Brill, 1977), 24-5, 121-23; S. Rappaport, Agada und Exegese bei Flavius Josephus (Frankfurt a. M.: Kauffmann,

Journal for the Study of Judaism, Vol. 32 (2001): pg. 137-158. DOI. This article is (C) Brill Academic Publishers and permission has been granted for this version to appear in e-Publications@ Marquette. Brill Academic Publishers does not grant permission for this article to be further copied/distributed or hosted elsewhere without the express permission from Brill Academic Publishers. 
1930), 6-9, 87-90; M. E. Stone, Armenian Apocrypha Relating to Adam and Eve (SVTP, 14; Leiden: Brill, 1996), 151, 198; M. E. Stone, "Selections from 'On the Creation of the World' by Yovhannes Tulkuranci," Literature on Adam and Eve (eds. G. Anderson et al.; SVTP, 15; Leiden: Brill, 2000), 210.

8 The Biblical concept of the two tablets, found in Ex 31-34, transcends the boundaries of the current research.

${ }^{9}$ On the figure of Seth and Sethian traditions see: T. Gluck, The Arabic Legend of Seth, the Father of Mankind (Ph.D. diss., Yale University, 1968); A. Klijn, Seth in Jewish, Christian and Gnostic Literature (SNT, 46; Leiden: Brill, 1977); R. Kraft, "Philo on Seth: Was Philo Aware of Traditions Which Exalted Seth and His Progeny?" The Rediscovery of Gnosticism (2 vols.; ed. B. Layton; SHR, 41; Leiden: Brill, 1981), 2.457-8; G. MacRae, "Seth in Gnostic Texts and Traditions," SBLSP 11 (1977) 24-43; B. Pearson, "The Figure of Seth in Gnostic Literature," The Rediscovery of Gnosticism (2 vols.; ed. B. Layton; SHR, 41; Leiden: Brill, 1981), 2.472-504; E. C. Quinn, The Quest of Seth for the Oil of Life (Chicago: University of Chicago, 1962); M. Stone, "Report on Seth traditions in the Armenian Adam Books," The Rediscovery of Gnosticism (2 vols.; ed. B. Layton; SHR, 41; Leiden: Brill, 1981), 2.459-71.

${ }^{10}$ E. Jeffreys, M. Jeffreys \& R. Scott, The Chronicle of John Malalas (Byzantina Australiensia, 4; Melbourne: Australian Association for Byzantine Studies, 1986).

${ }^{11}$ Another Christian chronographer, George the Monk, also notices this feature: "...For the descendants of Seth had been warned in advance from on high about the coming destruction of mankind, and made two stelae, one of stone, the other of brick; and they wrote on them all the celestial knowledge set forth their father Seth, ... as Josephus says." Adler, Time Immemorial: Archaic History and Its Sources in Christian Chronography from Julius Africanus to George Syncellus, 215. For the Greek text see: Georgii Monachi Chronicon (2 vols.; ed. C. de Boor; Leipzig: Teubner, 1904), 1.10.

12 E. Jeffreys, M. Jeffreys \& R. Scott, The Chronicle of John Malalas (Byzantina Australiensia, 4; Melbourne: Australian Association for Byzantine Studies, 1986), 4.

${ }^{13}$ See 1 Enoch 12-14.

${ }^{14}$ See Jub. 4:23.

${ }^{15}$ See 4Q203 8: "scri[be...] [...] Copy of the seco[n]d tablet of [the] le[tter...] by the hand of Enoch, the distinguished scribe [...] and holy (one), to Shemihazah and to all [his] com[panions...] You should know th[at] no[t...] and your deeds and those of your wives [...] they [and the]ir sons and the wives o[f their sons...] for [yo]ur prostitution in the [I]and. It will happen [t]o yo[u...] and lodges a complaint against you and against the deeds of your sons [...] the corruption with which you

Journal for the Study of Judaism, Vol. 32 (2001): pg. 137-158. DOI. This article is @ Brill Academic Publishers and permission has been granted for this version to appear in e-Publications@Marquette. Brill Academic Publishers does not grant permission for this article to be further copied/distributed or hosted elsewhere without the express permission from Brill Academic Publishers. 
have corrupted it. [...] until the coming of Raphael. Behold, destruction [...] and which are in the deserts and whi[ch] are in the seas. And tear loose [the] totality [of...] upon you for evil. Now, then, unfasten your chains which ti[e (you)...] and pray. [...]." F. García Martínez and E. J. C. Tigchelaar (eds.), The Dead Sea Scrolls Study Edition (2 vols.; Leiden; New York; Köln: Brill, 1997), 1.411.

16 "However, we found that Enosh, son of Seth, made the letter(s) and called the planets by name. And he prophesied that this world would pass away twice, by water and by fire. And he made two stelae, of bronze and of clay, and he wrote upon them the names of the parts of creation which Adam had called. He said, 'If it passes away by water, then the bronze (will) remain, and if by fire, then the fired clay."' M. E. Stone, Armenian Apocrypha Relating to Adam and Eve (SVTP, 14; Leiden: Brill, 1996), 151.

${ }^{17}$ Ioannis Malalae Chronographia (ed. L. Dindorf; CSHB; Bonn: Weber, 1831), 5.

${ }^{18}$ A Synopsis of the Books of Adam and Eve (2nd rev.ed.; eds. G. Anderson and M. Stone; Early Judaism and Its Literature, 17; Atlanta: Scholars, 1999), 96E.

${ }^{19}$ In 1 Enoch 74:2, Enoch writes the instructions of the angel Uriel regarding the secrets of heavenly bodies and their movements. $M$. Knibb, The Ethiopic Book of Enoch: A New Edition in the Light of the Aramaic Dead Sea Fragments (2 vols; Oxford: Clarendon Press, 1978), 2.173. Adler draws the reader's attention to an interesting passage from Michael Glycas which refers to Uriel's instruction to Seth in a manner similar to Uriel's revelation of the calendarical and astronomical secrets to Enoch in the Astronomical Book of 1 Enoch. "It is said that the angel stationed among the stars, that is the divine Uriel, descended to Seth and then to Enoch and taught them the distinctions between hours, months, seasons, and years." Adler, Time Immemorial: Archaic History and Its Sources in Christian Chronography from Julius Africanus to George Syncellus, 105. For the Greek text see: Michaelis Glycae Annales (ed. I. Bekker; CSHB; Bonn: Weber, 1836), 228.

20 4Q203 8: "...Copy of the seco[n]d tablet of [the] le[tter...] by the hand of Enoch, the distinguished scribe..." F. García Martínez and E. J. C. Tigchelaar (eds.), The Dead Sea Scrolls Study Edition (2 vols.; Leiden; New York; Köln: Brill, 1997), 1.411.

21 J. C. VanderKam, The Book of Jubilees (2 vols.; CSCO, 510-11; Scriptores Aethiopici, 87-88; Leuven: Peeters, 1989), 2.25-6. 22 This tradition can be seen already in 2 Enoch 23:4-6, which depicts the angel Vereveil commanding Enoch to sit down: "You sit down; write everything....' And Enoch said, 'And I sat down for a second period of 30 days and 30 nights, and I wrote accurately."' F. I. Andersen, "2 (Slavonic Apocalypse of) Enoch," The Old Testament 
Pseudepigrapha (2 vols.; ed. J. H. Charlesworth; New York:

Doubleday, 1985 [1983]), 1.141.

23 Josephus, Jewish Antiquities, 4.33.

24 F. I. Andersen, "2 (Slavonic Apocalypse of) Enoch," The Old

Testament Pseudepigrapha (2 vols.; ed. J. H. Charlesworth; New York: Doubleday, 1985 [1983]), 1.156.

25 On Enoch's role as the knower of the secrets see: Andrei A. Orlov, "Secrets of Creation in 2 (Slavonic) Enoch," Henoch 22 (2000) 45-62.

${ }^{26}$ H. S. Kvanvig, Roots of Apocalyptic: the Mesopotamian Background of the Enoch Figure and of the Son of Man (WMANT, 61; NeukirchenVluyn: Neukirchener Verlag, 1988), 27.

27 Josephus, Jewish Antiquities, 4.33.

${ }^{28}$ Adler, Time Immemorial: Archaic History and Its Sources in Christian Chronography from Julius Africanus to George Syncellus, 105; Michaelis Glycae Annales (ed. I. Bekker; CSHB; Bonn: Weber, 1836), 228.

29 M. E. Stone, Armenian Apocrypha Relating to Adam and Eve (SVTP, 14; Leiden: Brill, 1996), 151.

30 "...the names which Seth, the son of Adam, and his children had given the stars, as the most learned Josephus has written in the second book of his Archeology." E. Jeffreys, M. Jeffreys \& R. Scott, The Chronicle of John Malalas (Byzantina Australiensia, 4; Melbourne:

Australian Association for Byzantine Studies, 1986), 4.

31 Ioannis Malalae Chronographia (ed. L. Dindorf; CSHB; Bonn: Weber, 1831), 5-6.

32 M. Knibb, The Ethiopic Book of Enoch (2 vols; Oxford: Clarendon, 1978), 2.128.

33 P. Alexander "3 (Hebrew Apocalypse of) Enoch," The Old Testament Pseudepigrapha (2 vols.; ed. J. H. Charlesworth; New York:

Doubleday, 1985 [1983]), 1.264.

34 M. E. Stone, Armenian Apocrypha Relating to Adam and Eve (SVTP, 14; Leiden: Brill, 1996), 151.

${ }^{35}$ APOT 2.18.

${ }^{36}$ Adler, Time Immemorial: Archaic History and Its Sources in Christian Chronography from Julius Africanus to George Syncellus, 105.

37 Vanderkam, Enoch: A Man for All Generation, 153.

38 J. Reeves, "Utnapishtim in the Book of Giants?" JBL 12 (1993) 11015.

${ }^{39}$ Vanderkam, The Book of Jubilees, 2.27-28.

40 See $4 Q 2038$.

41 Andersen, 1.130-33.

42 b. Sanh. 108b refers to a flood of water and a flood of fire. See Klijn, Seth in Jewish, Christian and Gnostic Literature, 122. 
43 M. E. Stone, Armenian Apocrypha Relating to Adam and Eve (SVTP, 14; Leiden: Brill, 1996), 198-200.

44 M. E. Stone, Armenian Apocrypha Relating to Adam and Eve (SVTP, 14; Leiden: Brill, 1996), 151-2.

${ }^{45} \mathrm{M}$. Stone observes that the Sethites are often called angels in some Greek patristic and Byzantine sources. Cf. M. E. Stone, Armenian Apocrypha Relating to Adam and Eve (SVTP, 14; Leiden: Brill, 1996), 150.

${ }^{46}$ M. E. Stone, Armenian Apocrypha Relating to Adam and Eve (SVTP, 14; Leiden: Brill, 1996), 150. Adler, Time Immemorial: Archaic History and Its Sources in Christian Chronography from Julius Africanus to George Syncellus, 113-116. For a Christian interpretation of the "sons of God" see Fraade, Enosh and His Generation, 47-107.

${ }^{47}$ Cf. Adler, Time Immemorial: Archaic History and Its Sources in Christian Chronography from Julius Africanus to George Syncellus, 92. ${ }^{48}$ Cf. 1 Enoch 6:6: "And they were in all two hundred, and they came down on Ardis which is the summit of Mount Hermon." M. Knibb, The Ethiopic Book of Enoch (2 vols.; Oxford: Clarendon, 1978), 2.68.

49 M. E. Stone, Armenian Apocrypha Relating to Adam and Eve (SVTP, 14; Leiden: Brill, 1996), 151.

50 "On these stones was found what Enoch, the seventh from Adam, prophesied before the flood about the coming of Christ: "Behold the Lord will come in his sanctuary (in his holy soldiers, in his soldiers, in his holy clouds?) to render judgment on all and to accuse the impious of all their works by which they have spoken concerning him-sinners, impious murmurers, and the irreligious who have lived according to their feelings of desire, and whose mouths have spoken pridefully." $A$ Synopsis of the Books of Adam and Eve (2nd rev. ed.; eds. G. Anderson and M. Stone; Early Judaism and Its Literature, 17; Atlanta: Scholars, 1999), 96E. For the Latin text of Vita, see also: W. Meyer, "Vita Adae et Evae," Abhandlungen der königlichen Bayerischen Akademie der Wissenschaften, philosoph.-philologische Klasse (Munich, 1878), 14.3:185-250; J. H. Mozley, "The Vitae Adae," JTS 30 (1929) 121-49.

${ }^{51}$ On Palaea Historica see: D. Flusser, "Palaea Historica-An Unknown Source of Biblical Legends," Studies in Aggadah and Folk-Literature (eds. J. Heinemann and D. Noy; Scripta Hierosolymitana, 22; Jerusalem: Magnes, 1971), 48-79; M. N. Speranskij, Is istorii russkoslavjanskih literaturnyh svjazei (Moscow: 1960), 104-47; Émile Turdeanu, Apocryphes Slaves et Roumains de l'Ancien Testament (SVT, 5; Leiden: Brill, 1981), 392-403; V. Tvorogov, "Paleja Istoricheskaja," in: Slovar' knizhnikov i knizhnosti Drevnei Rusi (Vtoraja polovina XIV-XVI v.) (2 vols.; ed. D. S. Lihachev; Leningrad: Nauka, 1989), 2.160-61; On various manuscripts of Palaea Historica

Journal for the Study of Judaism, Vol. 32 (2001): pg. 137-158. DOI. This article is (C) Brill Academic Publishers and permission has been granted for this version to appear in e-Publications@Marquette. Brill Academic Publishers does not grant permission for this article to be further copied/distributed or hosted elsewhere without the express permission from Brill Academic Publishers. 
NOT THE PUBLISHED VERSION; this is the author's final, peer-reviewed manuscript. The published version may be accessed by following the link in the citation at the bottom of the page.

cf. A. Vassiliev, Anecdota Graeco-Byzantina (Moscow, 1893), L-LI. 52 A. Vassiliev, Anecdota Graeco-Byzantina (Moscow, 1893), 196-98. 53 One will recall that the Josephus account has Noah, rather than Enoch, preach to the Giants.

${ }^{54}$ In Palaea the story of Noah looms large. The two tablets story is situated in the middle of a large Noachic account which occupies three chapters in Palaea Historica. Unfortunately, in our presentation of the Palaea fragment, we were unable to reproduce this lengthy Noachic narrative. For the full text of the Noachic account see A. Vassiliev, Anecdota Graeco-Byzantina (Moscow, 1893), 196-200.

55 On Noachic traditions see: M. Bernstein, "Noah and the Flood at Qumran," The Provo International Conference on the Dead Sea Scrolls: Technological Innovations, New Texts, and Reformulated Issues (eds. D. W. Parry and E. Ulrich; STDJ, 30; Leiden: Brill, 1999), 199-231; D. Dimant, "Noah in Early Jewish Literature," Biblical Figures Outside the Bible (eds. M. E. Stone and T. A. Bergren; Harrisburg: Trinity Press International, 1998), 123-50; F. García Martínez, Qumran and Apocalyptic (STDJ, 9; Leiden: Brill, 1992), 24-44; F. García Martínez, "Interpretation of the Flood in the Dead Sea Scrolls," Interpretations of the Flood (eds. F. García Martínez and G. P. Luttikhuizen; TBN, 1; Leiden: Brill, 1998), 86-108; H. Kvanvig, Roots of Apocalyptic. The Mesopotamian Background of the Enoch Figure and the Son of Man (WMANT, 61; Neukirchen-Vluyn: Neukirchener Verlag, 1988), 242-54; J. Lewis, A Study of the Interpretation of Noah and the Flood in Jewish and Christian Literature (Leiden: Brill, 1968); A. Orlov, "'Noah's Younger Brother': The Anti-Noachic Polemics in 2 Enoch," Henoch 22 (2000) 207-21; J. Reeves, "Utnapishtim in the Book of Giants?" JBL 12 (1993) 110-15; J. M. Scott, "Geographic Aspects of Noachic Materials in the Scrolls of Qumran," The Scrolls and the Scriptures: Qumran Fifty Years After (eds. S. E. Porter and C. E. Evans; JSPS, 26; Sheffield: Sheffield Academic Press, 1997), 368-81; R. C. Steiner, "The Heading of the Book of the Words of Noah on a Fragment of the Genesis Apocryphon: New Light on a 'Lost' Work," DSD 2 (1995) 66-71; M. Stone, "The Axis of History at Qumran," Pseudepigraphic Perspectives: The Apocrypha and the Pseudepigrapha in Light of the Dead Sea Scrolls (eds. E. Chazon and M. E. Stone; STDJ, 31; Leiden: Brill, 1999), 133-49; M. Stone, "Noah, Books of," Encyclopaedia Judaica (Jerusalem: Keter, 1971), 12.1198; J. VanderKam, "The Righteousness of Noah," Ideal Figures in Ancient Judaism: Profiles and Paradigms (eds. J. J. Collins and G. W. E. Nickelsburg; SBLSCS, 12; Chico: Scholars Press, 1980), 13-32; J. VanderKam, "The Birth of Noah," Intertestamental Essays in Honor of Jósef Tadeusz Milik (ed. Z. J. Kapera; Qumranica Mogilanensia, 6; Krakow: Enigma, 1992), 21331; Cana Werman, "Qumran and the Book of Noah" Pseudepigraphic Perspectives: The Apocrypha and the Pseudepigrapha in Light of the

Journal for the Study of Judaism, Vol. 32 (2001): pg. 137-158. DOI. This article is @ Brill Academic Publishers and permission has been granted for this version to appear in e-Publications@Marquette. Brill Academic Publishers does not grant permission for this article to be further copied/distributed or hosted elsewhere without the express permission from Brill Academic Publishers. 
Dead Sea Scrolls (eds. E. Chazon and M. E. Stone; STDJ, 31; Leiden: Brill, 1999), 171-81.

56 The influence of the Adamic tradition(s) can be found in the majority of the two stelae stories which are based on the Josephus account. 57 See M. Stone, "The Axis of History at Qumran," Pseudepigraphic Perspectives: The Apocrypha and the Pseudepigrapha in the Light of the Dead Sea Scrolls (eds. E. Chazon and M. E. Stone; STDJ, 31; Leiden: Brill, 1999), 133-49.

58 4Q530: "...Then two of them dreamed dreams, and the sleep of their eyes and come to [...] their dreams. And he said in the assembly of [his frien]ds, the Nephilin, [...in] my dream; I have seen in this night $[\ldots]$ gardeners and they were watering $[\ldots]$ numerous roo[ts] issued from their trunk [...] I watched until tongues of fire from [...] all the water and the fire burned in all [...] Here is the end of the dream." F. García Martínez and E. J. C. Tigchelaar (eds.), The Dead Sea Scrolls Study Edition (2 vols.; Leiden; New York; Köln: Brill, 1997), 2.1063.

${ }^{59}$ Some scholars point to a possible Mesopotamian background in this imagery of the dual destruction of the world. Cf. Klijn, Seth in Jewish, Christian and Gnostic Literature, 24, 123; J. Reeves, Jewish Lore in Manichaean Cosmology: Studies in the Book of Giants Traditions (Monographs of the Hebrew Union College, 14; Cincinnati: Hebrew Union College Press, 1992), 145.

${ }^{60}$ Reeves, Jewish Lore in Manichaean Cosmology, 88.

${ }^{61}$ Milik, The Books of Enoch (Oxford: Clarendon, 1976), 321-330;

Reeves, Jewish Lore in Manichaean Cosmology, 86-7; L. Stuckenbruck, The Book of Giants from Qumran Texts, Translation, and Commentary (TSAJ, 63; Tübingen: Mohr/Siebeck, 1997), 114-15.

${ }^{62}$ On Midrash Abkir see: H. L. Strack and G. Stemberger, Introduction to the Talmud and Midrash (Edinburg: T\&T Clark, 1991), 341; A.

Marmorstein, "Midrash Abkir," Debir 1 (1923) 113-44.

${ }^{63}$ For a detailed discussion of the similarities see: Reeves, Jewish Lore in Manichaean Cosmology, 86-7. For the criticism of Reeves' position see: L. Stuckenbruck, The Book of Giants from Qumran: Texts, Translation, and Commentary (TSAJ, 63; Tübingen: Mohr/Siebeck, 1997), 115.

${ }^{64}$ Milik, The Books of Enoch, 328.

${ }^{65}$ Cf. J. D. Eisenstein, Otzar midrashim (2 vols.; New York: J. D. Eisenstein, 1915), 2.549-50; A. Jellinek, Bet ha-Midrasch (6 vols.; Jerusalem: Wahrmann, 1967), 4.127-28; Ch. Albeck, Midrash Bereshit Rabbati (Jerusalem: Mekitze Nirdamim, 1940), 29-31; R. Martini, Pugio Fidei adversus Mauros et Judaeos (Lipsiae: Sumptibus haeredum F. Lanckisi, 1687), 937-39.

66 The Chronicles of Jerahmeel (tr. M. Gaster; Oriental Translation Fund, 4; London: Royal Asiatic Society, 1899).

Journal for the Study of Judaism, Vol. 32 (2001): pg. 137-158. DOI. This article is (C) Brill Academic Publishers and permission has been granted for this version to appear in e-Publications@Marquette. Brill Academic Publishers does not grant permission for this article to be further copied/distributed or hosted elsewhere without the express permission from Brill Academic Publishers. 
67 The Chronicles of Jerahmeel (tr. M. Gaster; Oriental Translation Fund, 4; London: Royal Asiatic Society, 1899), 51.

$68 \mathrm{M}$. Gaster in his commentary on both passages about the two tablets' tradition noted that "...in chapter 26 our compiler seems to have intercalated from the middle of paragraph 15 on to the end of 20 a tradition that occurs once before in chapter 24, paragraph 6-9, and which is missing in the Latin. It is not at all improbable that this portion belongs to the old original." The Chronicles of Jerahmeel, Ixxv. 69 "...Jubal heard the prophesy of Adam concerning two judgments about to come upon the world by means of the flood, the dispersion and fire, that he wrote down the science of music upon two pillars, one of fine white marble and the other of brick, so that in the event of the one melting and being destroyed by the waters, the other would be saved. 26:15-20." The Chronicles of Jerahmeel, 56.

70 "... and Enoch-who was the author of many writings-walked with God, and was no more, for God had taken him away and placed him in the Garden of Eden, where he will remain until Elijah shall appear and restore the hearts of the fathers to the children. And the Flood took place." The Chronicles of Jerahmeel, 57.

${ }^{71}$ Another distinctive feature in Jubal's story is that it refers to white marble as one of the materials used for the stelae. As far as I know, the only other text that refers to this component in the "two stelae" stories is Enoch's account from Palaea Historica.

72 Additional evidence that the motif of fire destruction played an important role in the Book of Giants is a passage from George Syncellus, which some scholars believe might be related to the textual tradition of the Book of Giants. See: Milik, The Books of Enoch, 31820; Adler, Time Immemorial, 179. Syncellus' fragment describes the fire destruction of Mount Hermon, the prominent topos where the Watchers' descent once took place. The text preserved in Syncellus reads: "... and again, concerning the mountain, on which they swore and bound themselves by oath, the one to the other, not to withdraw from it for all eternity: There will be descend on it neither cold, nor snow, nor frost, nor dew, unless they descend on it in malediction, until the day of the Great Judgment. At that time it will be burned and brought low, it will be consumed and melted down, like wax by fire. Thus it will be burned as a result of all its works...." Milik, The Books of Enoch, 318. For the critical edition of the text see: Georgius Syncellus, Ecloga Chronographica (ed. A. A. Mosshammer; Bibliotheca Scriptorum Graecorum et Romanorum Teubneriana; Leipzig: Teubner, 1984), 267. The story of fire destruction of Mount Hermon in Syncellus echoes 1 Enoch 10:13-16, where God tells Michael that He has prepared the destruction by fire for the Watchers.

73 The first group of fragments is connected with the final fire punishment of "sinners" (in Henning's opinion, "sinners" represent the

Journal for the Study of Judaism, Vol. 32 (2001): pg. 137-158. DOI. This article is @ Brill Academic Publishers and permission has been granted for this version to appear in e-Publications@Marquette. Brill Academic Publishers does not grant permission for this article to be further copied/distributed or hosted elsewhere without the express permission from Brill Academic Publishers. 
Watchers and the Giants) under the eyes of the Righteous. Henning believes that this group of texts belonged to the Kawân. F- "(Col. D) ...sinners... is visible, where out of this fire your soul will be prepared (for the transfer) to eternal ruin (?). And as for you, sinful misbegotten sons of the Wrathful Self, cofounders of the true words of that Holy One, disturbers of the action of Good Deed, aggressors upon Piety,...ers of the Living..., who their...

(Col. E)... and on brilliant wings they shall fly and soar further outside and above that Fire, and shall gaze into its depth and height. And those Righteous that will stand around it, outside and above, they themselves shall have power over that Great Fire, and over everything in it...blaze...souls that...

(Col.F)...they are purer and stronger [than the] Great Fire of Ruin that sets the worlds ablaze. They shall stand around it, outside and above, and splendor shall shine over them. Further outside and above it they shall fly (?) after those souls that may try to escape from the Fire. And that..." W. B. Henning, "The Book of the Giants," BSOAS 11 (1943-46) 72.

742 Q26 "[...and] they washed the tablet to er[ase...] [...] and the water rose above the $[$ tab]let $[. .].[\ldots]$ and they lifted the tablet from the water, the tablet which $[\ldots][\ldots] . . .[\ldots]$ to them all $[\ldots] . "$ F. García Martínez and E. J. C. Tigchelaar (eds.), The Dead Sea Scrolls Study Edition (2 vols.; Leiden; New York; Köln: Brill, 1997), 1.221.

75 4Q203 7BII: "[...] [...] to you, Maha[wai...] the two tablets [...] and the second has not been read up till now [...]." F. García Martínez and E. J.C. Tigchelaar (eds.), The Dead Sea Scrolls Study Edition (2 vols.; Leiden; New York; Köln: Brill, 1997), 1.411.

76 4Q203 8: "...Copy of the seco[n]d tablet of [the] le[tter...] by the hand of Enoch, the distinguished scribe [...] and holy (one), to

Shemihazah and to all [his] com[panions...] ..." F. García Martínez and E. J. C. Tigchelaar (eds.), The Dead Sea Scrolls Study Edition (2 vols.; Leiden; New York; Köln: Brill, 1997), 1.411.

77 W. Sundermann, "Ein weiteres Fragment aus Manis Gigantenbuch," Orientalia J. Duchesne-Guillemin emerito oblata (Acta Iranica, 23; Leiden: Brill, 1984), 491-505.

78 "One saw a great stone spread over the earth like a table, the whole of which was written over with lines (of writing). And an angel (was seen by him) descending from the firmament with a knife in his hand and he was erasing and obliterating all the lines, save one line with four words upon it." Milik, The Books of Enoch, 328.

79 W. Sundermann, "Ein weiteres Fragment aus Manis Gigantenbuch," Orientalia J. Duchesne-Guillemin emerito oblata (Acta Iranica, 23; Leiden: Brill, 1984), 495-6.

${ }^{80}$ F. García Martínez and E. J. C. Tigchelaar (eds.), The Dead Sea Scrolls Study Edition (2 vols.; Leiden; New York; Köln: Brill, 1997), 
NOT THE PUBLISHED VERSION; this is the author's final, peer-reviewed manuscript. The published version may be accessed by following the link in the citation at the bottom of the page.

1.411 .

81 The "mediating" function of Enoch remains prominent during the whole history of the Enochic traditions. It has been shown previously that in 1 Enoch and 2 Enoch, the seventh antediluvian patriarch "transmits" celestial knowledge to various human and angelic agents. In the Merkabah tradition, Metatron/Enoch is also responsible for transmitting the highest secrets to the Princes under him and to humankind.

82 On Enoch's roles see A. Orlov, "Titles of Enoch-Metatron in 2 Enoch," JSP 18 (1998) 71-86.

${ }^{83} \mathrm{Cf} .4 Q 203$ 8:6-15 and possibly 2Q26. Apparently the last one

pictures an attempt to erase (wash out) this record of inequities: $2 Q 26$

"[...and] they washed the tablet to er[ase...] and the water rose above the [tab]let [...] and they lifted the tablet from the water, the tablet which [...] to them all [...]." F. García Martínez and E. J. C. Tigchelaar (eds.), The Dead Sea Scrolls Study Edition (2 vols.; Leiden; New York; Köln: Brill, 1997), 1.221.

84 F. García Martínez, Qumran and Apocalyptic, 110.

85 Palaea Historica alludes to the fact that Enoch starts writing tablets only after the Giants rejected his call to repentance.

${ }^{86}$ Adler, Time Immemorial: Archaic History and Its Sources in Christian Chronography from Julius Africanus to George Syncellus, 91, n. 68.

87 Cf. Adler, Time Immemorial: Archaic History and Its Sources in Christian Chronography from Julius Africanus to George Syncellus, 91, n. 68 and 181-82.

Journal for the Study of Judaism, Vol. 32 (2001): pg. 137-158. DOI. This article is (C) Brill Academic Publishers and permission has been granted for this version to appear in e-Publications@Marquette. Brill Academic Publishers does not grant permission for this article to be further copied/distributed or hosted elsewhere without the express permission from Brill Academic Publishers. 